\title{
Bahan Ajar Determinan dan Invers Matriks Berbasis Android untuk SMA Kelas XI
}

\author{
Devi Wahyu Safitri ${ }^{1^{*}}$, Zulkardi $^{2}$, Hapizah $^{3}$, \\ ${ }^{1,2,3}$ Universitas Sriwijaya, Jl Palembang-Prabumulih KM 32 Indralaya, Indonesia
}

Pengiriman: 06/Juni/2020; Diterima: 23/September/2020; Publikasi: 30/September/2020

DOI: https://doi.org/10.31629/jg.v5i2.2306

\begin{abstract}
Abstrak
Penelitian ini bertujuan untuk: (1) menghasilkan bahan ajar determinan dan invers matriks berbasis android untuk SMA Kelas XI yang valid dan praktis, dan (2) mengetahui efek potensialnya terhadap hasil belajar peserta didik kelas XI. IPA 6 SMA Negeri 8 Palembang yang terdiri dari 34 orang sebagai subjek penelitian. Penelitian ini merupakan jenis penelitian pengembangan atau development research yang terdiri dari dua tahapan, yaitu: tahap preliminary meliputi analisis dan desain, dan tahap formative evaluation meliputi self evaluation, prototyping (expert review, one to one, small group), dan field test. Teknik pengumpulan data dengan walkthrough, observasi, wawancara dan tes. Hasil dari penelitian ini adalah: (1) bahan ajar determinan dan invers matriks berbasis android untuk SMA Kelas XI terkategori valid dan praktis, dan (2) bahan ajar yang dikembangkan memiliki efek potensial terhadap hasil belajar peserta didik rata-rata terkategori baik, yaitu 13 orang memiliki kemampuan dalam kategori sangat baik, 12 orang terkategori baik, 4 orang terkategori cukup, dan 5 orang terkategori kurang.
\end{abstract}

Kata kunci: bahan ajar; android; determinan; invers

\begin{abstract}
This research aims: (1) to produce a valid and practical android based teaching materials on the material of determinant and inverse of matrix for 11th grade, and (2) to know its potential effects on the results of $11^{\text {th }}$ grade Science 6 in Senior High School 8 Palembang which there are 34 people as subjects of research. This research is a development research which is focused on two stages, namely preliminary stage that consisted of analysis and design, and formative evaluation stage that consisted of self evaluation, prototyping (expert review, one to one, small group), and field test. Data collecting techniques used are walkthrough, interviews, observations, and tests. The results of this research are: (1) valid and practical android based teaching materials on the material of determinant and inverse of matrix for 11th grade Senior High School, and (2) the teaching materials developed have a potential effect on learning result of $11^{\text {th }}$ grade Science 6 Senior High School 8 Palembang with a good average, which is that 13 people have a very good category, 12 categories good category, 4 categories sufficient, and 5 categories less.
\end{abstract}

Keywords: teaching materials; android; determinant; inverse

*Penulis Korespondensi

Email Address: deviw737@gmail.com

Handphone : : +6288274389366 


\section{JURNAL GANTANG. September 2020; V(2): 151 - 162 \\ p-ISSN. 2503-0671 \\ e-ISSN. 2548-5547}

\section{Pendahuluan}

Revolusi industri 4.0 kini telah merambah ke seluruh penjuru dunia di mana istilah ini lahir dari ide tentang revolusi industri keempat yang keberadaannya menawarkan banyak potensi manfaat. Hadirnya revolusi ini telah menjadikan teknologi informasi sebagai basis dalam kehidupan manusia, sehingga tantangan revolusi 4.0 harus direspon cepat dan tepat (Menristekdikti, 2018). Dalam menghadapinya tentu menuntut kesiapan setiap negara khususnya Indonesia untuk mampu dengan cepat beradaptasi pada perubahan yang ada terutama pada bidang pendidikan, dimana sistem pembelajaran yang semula tatap muka di kelas bukan tidak mungkin akan digantikan dengan sistem pembelajaran melalui jaringan internet atau online learning (Rahayu, 2018).

Maju dan tidaknya suatu negara dapat dilihat dari kemajuan sistem pendidikannya. Oleh karena itu, guru dituntut untuk memiliki kompetensi tinggi dalam menghadapi revolusi industri 4.0. Setidaknya menurut Qusthalani (2018) terdapat 5 kualifikasi dan kompetensi guru yang dibutuhkan pada era revolusi ini, yaitu educational competence, competence for technological commercialization, competence in globalization, competence in future strategies, dan conselor competence. Berdasarkan hal tersebut, kebutuhan pembelajaran yang dapat disiapkan salah satunya ialah media pembelajaran berupa aplikasi non-paper yang disajikan secara menarik dalam bentuk animasi, gambar, video, dan lain-lain (Qusthalani, 2018). Dalam hal ini, bahan ajar disebut sebagai bagian penting dalam pelaksanaan pendidikan di sekolah, sebab memberi kemudahan guru dalam melaksanakan pembelajaran dan membantu peserta didik mudah untuk belajar (Depdiknas, 2008).

Depdiknas (2008) mengharapkan agar para guru di sekolah mengembangkan bahan ajar yang beragam dan menarik agar menghasilkan suatu kegiatan belajar mengajar yang bermakna dengan menerapkan prinsip pembelajaran yang salah satunya ialah dari yang kongkret untuk

memahami yang abstrak. Hal ini sejalan dengan salah satu karakteristik matematika yaitu memiliki objek (fakta, konsep, operasi, dan prinsip) kajian abstrak (Susanah, 2007).

Determinan dan invers matriks merupakan salah satu pokok bahasan matematika, yang menurut kurikulum 2013 di pelajari di kelas 11 semester 1. Determinan matriks A ditulis det (A) yang berodo $2 \times 2$ diperoleh dengan cara mengurangkan hasil kali elemen-elemen diagonal utama dengan hasil kali elemen-elemen diagonal kedua (Aksin, Ngapiningsih, Miyanto, \& Astuti, 2017). Invers matriks disebut juga kebalikan matriks (Kemdikbud, 2017). Namun, dalam memahami materi ini ditemukan kesulitan-kesulitan di dalamnya. Hasil penelitian Halid (2016) menunjukkan sebesar $36 \%$ dari 24 orang peserta didik mengalami kesulitan memahami konsep dan rumus-rumus matriks seperti invers, determinan dan transpos matriks. Pada hasil penelitian lain dinyatakan bahwa peserta didik masih melakukan kesalahan dalam mencari determinan dan invers karena tidak mengerti syarat mencari invers matriks (Krismantono \& Purnami, 2016).

Berdasarkan hal tersebut, maka perlunya peningkatan kemampuan peserta didik dalam memahami konsep materi determinan dan invers matriks. Pemahaman konsep merefleksikan suatu kemampuan peserta didik dalam situasi atau konteks yang melibatkan pengaplikasian yang hati-hati dalam memberikan penjelasan serta alasan yang terukur dari definisi konsep-konsep, relasi-relasi, atau representasinya (Mulyono \& Hapizah, 2018). Sehingga, untuk meningkatkan pemahaman konsep matematika peserta didik dapat diwujudkan dengan menerapkan pendekatan saintifik (scientific approach) dalam pembelajaran di kelas (Istikomah \& Jana, 2018; Palaki \& Fahinu, 2015). Hal ini diperkuat oleh pernyataan Sulastra, dkk (2015) bahwa pendekatan saintifik dapat meningkatkan pemahaman konsep matematika peserta didik dengan persentase rata-rata dari $63,53 \%$ (sebelum penelitian) meningkat menjadi 80,36\% 
(kriteria tinggi). Pendekatan saintifik adalah konsep dasar yang melatarbelakangi perumusan metode mengajar dengan menerapkan karakteristik yang ilmiah (Musfiqon \& Nurdyansyah, 2015). Sehingga, dari beberapa pendapat tersebut untuk mengatasi kesulitan peserta didik dalam memahami konsep determinan dan invers matriks dapat dilakukan dengan menerapkan pembelajaran dengan pendekatan saintifik.

Pendekatan saintifik diyakini sebagai titian emas perkembangan dan pengembangan pada ranah sikap, pengetahuan, dan keterampilan peserta didik (Kementerian Pendidikan dan Kebudayaan, 2014). Proses pembelajaran pendekatan saintifik terdiri dari 5 pengalaman belajar pokok menurut Permendikbud Nomor 103 tahun 2014, yaitu mengamati, menanya, mengumpulkan informasi, mengasosiasi dan mengkomunikasikan. Bahan ajar yang akan dikembangkan peneliti menggunakan pendekatan saintifik, dikarnakan terbukti dapat meningkatkan hasil belajar peserta didik (Retnoningrum, Dasna, \& Santoso, 2016). Hidayah (2017) juga menyatakan desain pengembangan bahan ajar menggunakan tahapan pendekatan saintifik mendapatkan respon yang baik dari peserta didik dan berpengaruh terhadap peningkatan hasil belajar dengan nilai rata-rata pre-test 65 dan post-test 81,9.

Berdasarkan hal tersebut, maka bahan ajar yang dikembangkan disesuaikan dengan tahapan pendekatan saintifik yang dalam hal ini berupa pembelajaran multimedia yang interaktif atau melibatkan partisipasi peserta didik. Sebagaimana Novitasari (2016) menyebutkan sebelum dilakukan pembelajaran multimedia interaktif peserta didik hanya datang, duduk, dengar, catat, dan hafal di kelas kurang diberi kesempatan berimajinasi dalam memahami konsep pembelajaran matematika, sedangkan setelah dilakukan pembelajaran multimedia interaktif hasil belajar yang diperoleh lebih baik dari metode konvensional. Sejalan dengan pendapat tersebut, Jacoebsen, dkk (2009) menyatakan teknologi dapat membantu guru dalam membimbing peserta didik memahami abstraksi, fakta dan mencapai tujuan-tujuan di tingkat taksonomi kognitif yang lebih tinggi. Oleh karena itu, bahan ajar yang dikembangkan merupakan bahan ajar yang multimedia interaktif karena penggunaan bahan ajar multimedia interaktif memiliki pengaruh terhadap hasil belajar peserta didik pada ranah kognitif, afektif dan psikomotorik (Ghufron \& Risnawita, 2012).

Penyajian bahan ajar disajikan sesuai dengan revolusi saat ini, yaitu dalam bentuk aplikasi di smartphone android. Android adalah sistem operasi dan platform pemrograman yang dikembangkan oleh Google untuk ponsel cerdas dan perangkat seluler lainnya, seperti tablet (Google Developer Training Team, 2016). Jumlah pengguna smartphone dilansir dari Pew Research Center menunjukkan pengguna untuk umur 18-34 di Indonesia mengalami kenaikan yang pesat dalam rentang tahun 2013-2018 yaitu dari $17 \%$ menjadi $66 \%$ pengguna. Juga dilansir dari TribunJabar.id bahwa pasar smartphone di Indonesia masih didominasi oleh android karena di Indonesia sendiri android telah menguasai lebih dari $90 \%$ dan $75 \%$ di dunia. Berdasarkan hal ini, penggunaan android telah meluas di Indonesia baik dari kalangan muda hingga dewasa. Lebih lanjut, beberapa penelitian menunjukkan bahan ajar berbasis android yang disusun berdasarkan tahapan pendekatan saintifik memiliki respon positif atau baik, efektif dalam pembelajaran, dan dapat meningkatkan hasil belajar (Fazar, Zulkardi, \& Somakim, 2016; Jazuli, Azizah, \& Meita, 2018; Nurrasyid, 2019). Tidak hanya itu, berdasarkan hasil dari data angket, Sari, dkk (2020) menyatakan ketertarikan peserta didik dalam menggunakan bahan ajar berbasis android sebesar 93,33\%, dan sebesar 96,67\% menunjukkan peserta didik menjadi lebih bersemangat dan antusias belajar matematika menggunakan bahan ajar berbasis android.

Sebagaimana yang telah disebutkan, peneliti membuat bahan ajar materi determinan dan invers matriks kelas XI dikemas dalam bentuk aplikasi di smartphone android. Dalam 
JURNAL GANTANG. September 2020; V(2): 151 - 162

p-ISSN. 2503-0671

e-ISSN. 2548-5547

pembuatannya diperlukan software Adobe Flash Professional CS6, sebab software ini dapat membuat bahan ajar interaktif yang berbasis android. Adobe Flash terdiri dari serangkaian teknologi terintegrasi yang memungkinkan pengembang membangun aplikasi interaktif yang berjalan secara konsisten di beberapa perangkat seluler dan berbasis web (Corlan, 2011; Gerantabee \& AGI Creative Team, 2012). Oleh karena itu, software Adobe Flash Professional CS6 dapat digunakan untuk membuat bahan ajar interaktif berbentuk aplikasi berbasis android dengan berbagai feature yang dimiliki.

Berdasarkan uraian di atas, rumusan masalah dalam penelitian ini, yaitu: (1) bagaimana karakteristik bahan ajar berbasis android pada materi determinan dan invers matriks untuk SMA kelas XI yang valid dan praktis, dan (2) bagaimana efek potensial bahan ajar berbasis android pada materi determinan dan invers matriks kelas XI terhadap hasil belajar peserta didik kelas XI.IPA 6 SMA Negeri 8 Palembang. Penelitian ini bertujuan untuk menghasilkan bahan ajar determinan dan invers matriks kelas XI yang valid dan praktis dan untuk mengetahui efek potensial bahan ajar determinan dan invers matriks terhadap hasil belajar peserta didik kelas XI.IPA 6 SMA Negeri 8 Palembang. Hasil penelitian ini diharapkan bermanfaat sebagai media pembelajaran alternatif dalam proses pembelajaran bagi guru maupun peserta didik.

\section{Metode Penelitian}

Jenis penelitian ini adalah penelitian pengembangan (development research) yang difokuskan pada dua tahap menurut Akker (1999) yaitu tahap preliminary yang meliputi tahap analisis dan desain, serta tahap formative evaluation menurut Tessmer (1993) dan Zulkardi (2002) yang meliputi self evaluation, prototyping (expert review, one-to-one, small group), dan field test.

Prosedur tahap formative evaluation dapat dilihat pada Gambar 1 .

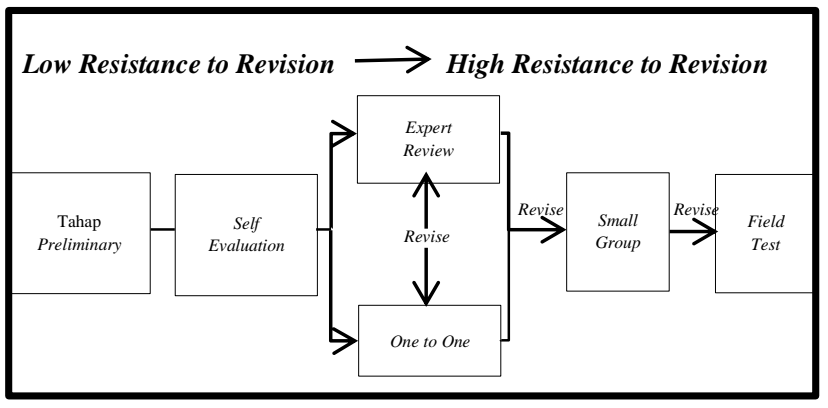

Gambar 1. Tahap-tahap formative evaluation (Tessmer, 1993; Zulkardi, 2002)

Adapun prosedur pengembangan sesuai gambar 1, yaitu sebagai berikut.

\section{Tahap Preliminary}

a. Analisis

Pada tahap ini peneliti akan melakukan analisis yaitu analisis kurikulum, kompetensi inti dan kompetensi dasar sesuai kurikulum 2013 SMA, analisis peserta didik, materi, dan kebutuhan peserta didik.

b. Desain

Peneliti mendesain atau merancang dan menyusun materi determinan dan invers matriks dalam bahan ajar yang disusun berdasarkan karakteristik, prinsip, dan tahapan dari pendekatan saintifik.

\section{Tahap Formative Evaluation}

a. Self Evaluation

Peneliti melakukan penilaian sendiri terhadap aplikasi bahan ajar determinan dan invers matriks berbasis android yang telah dikembangkan berdasarkan desain yang dibuat. Penilaian didasarkan atas validitas isi, konstruk, dan bahasa.

b. Expert Review

Proses expert review dilakukan dengan mengevaluasi produk prototype 1 dan berkonsultasi kepada ahli, pembimbing dan guru mengenai desain protipe pertama yang telah dibuat. Tahap ini dilakukan untuk uji kevalidan bahan ajar dengan teknik walkthrough.

c. One to One

Peneliti mengujicobakan prototype 1 kepada 3 orang peserta didik yang masing-masingnya diminta untuk memberikan komentar dan saran 
mengenai bahan ajar pada lembar komentar dan pengadaan wawancara tiap peserta didik. Komentar dan saran, serta hal-hal yang diperoleh dari wawancara terhadap peserta didik akan dijadikan sebagai perbaikan produk bahan ajar berbasis android yang peneliti kembangkan.

d. Small Group

Tahap ini dilakukan untuk mengukur kepraktisan penggunaan bahan ajar selama pembelajaran dengan observasi. Produk prototype 2 diujikan kepada 3 orang peserta didik kelas XI yang non subjek penelitian.

e. Field Test

Pada tahap ini, peneliti ingin mengetahui efek potensial terhadap hasil belajar peserta didik setelah menggunakan bahan ajar determinan dan invers matriks berbasis android yang dikembangkan. Tahap ini dilakukan selama 3 pertemuan, dengan menggunakan teknik tes, dan wawancara sebagai data pendukung mengenai efek potensial dari bahan ajar yang dikembangkan dengan mengetahui tanggapan, komentar, atau saran peserta didik.

Penelitian ini dilakukan di SMA Negeri 8 Palembang pada peserta didik kelas XI. Teknik pengumpulan data yang digunakan dalam penelitian ini adalah walkthrough, observasi, wawancara, dan tes.

Walkthrough disusun berdasarkan validitas isi, konstruk dan bahasa. Instrumen walkthrough diberikan kepada 2 orang validator media dan 3 orang validator materi di tahap expert review berupa lembar validasi materi, media, RPP, LKPD, soal tes dan pedoman wawancara, dan diberikan kepada 3 orang siswa di tahap one-to-one berupa lembar komentar saran. Selanjutnya, data walkthrough diolah dengan melakukan perbaikan berdasarkan penilaian, komentar dan saran dari validator dan siswa.
Pada observasi terdapat 5 pernyataan dengan 4 pilihan jawaban. Observasi dilakukan oleh 2 observer yaitu Tri Retno Handayani dan Suci Maharani. Data yang diperoleh dari hasil observasi di tahap small group dianalisis menggunakan:

$N_{A}=\frac{\text { Jumlah skor yang diperoleh }}{\text { Jumlah skor ideal }} \times 100$ (Arikunto, 2014). Nilai akhir $\left(N_{A}\right)$ yang diperoleh kemudian dikategorikan sesuai tabel 1. Cara analisis observasi ini dimodifikasi dari Sugiyono (2013).

Tabel 1.

Kriteria kepraktisan bahan ajar

\begin{tabular}{cc}
\hline $\begin{array}{c}\text { Nilai Presentase } \\
(\boldsymbol{\%})\end{array}$ & Kriteria \\
\hline $84 \leq N_{A} \leq 100$ & Sangat Praktis \\
$68 \leq N_{A}<84$ & Praktis \\
$52 \leq N_{A}<68$ & Cukup \\
$36 \leq N_{A}<52$ & Tidak Praktis \\
$20 \leq N_{A}<36$ & Sangat Tidak Praktis \\
\hline
\end{tabular}

Selain observasi, penelitian ini juga menggunakan tes tertulis untuk mengetahui efek potensial bahan ajar terhadap hasil belajar subjek penelitian, dengan nilai 70 sebagai kriteria ketuntasan minimal (KKM) kelas XI di sekolah tersebut. Tes tertulis dinilai berdasarkan rubrik penilaian, dan hasilnya dihitung dengan cara:

Nilai $=\frac{\text { Skor yang diperoleh }}{\text { Skor Maksimum }} \times 100 . \quad$ Selanjutnya nilai yang diperoleh diinterpretasikan dengan menggunakan kriteria pada tabel 2 yang diperoleh dari ketentuan berikut yang dimodifikasi dari Arikunto (2014)..

Nilai Maksimum $\quad: 100$

Nilai Minimum $\quad: 0$

Kategori Kriteria $\quad: 5$

Rentangan Nilai $\quad: \frac{100-0}{5}=\frac{100}{5}=20$

Tabel 2.

Kategori nilai berdasarkan nilai akhir

\begin{tabular}{cc}
\hline Nilai Akhir & Kategori Nilai \\
\hline $80<N_{A} \leq 100$ & Baik Sekali \\
\hline $60<N_{A} \leq 80$ & Baik \\
\hline $40<N_{A} \leq 60$ & Cukup \\
\hline $20<N_{A} \leq 40$ & Kurang \\
\hline $0 \leq N_{A} \leq 20$ & Gagal \\
\hline
\end{tabular}




\section{JURNAL GANTANG. September 2020; V(2): 151 - 162 \\ p-ISSN. 2503-0671 \\ e-ISSN. 2548-5547}

\section{Hasil dan Pembahasan}

\section{Deskripsi Produk Bahan Ajar Determinan} dan Invers Matriks

Produk yang dihasilkan dari penelitian ini adalah bahan ajar Determinan dan Invers Matriks berbasis android untuk SMA kelas XI yang berupa aplikasi (berformat apk.). Bahan ajar ini hanya dapat dipasang di smartphone android, artinya bahan ajar tidak dapat dijalankan pada smartphone yang menggunakan OS dan sebagainya. Kapasitas bahan ajar ini sebesar 260 MB dan setidaknya pengguna menyiapkan RAM sebesar $260-300 \mathrm{MB}$.

Bahan ajar ini beroperasi secara offline, sehingga pengguna dapat menggunakannya tanpa memperhitungkan sinyal dan kuota paket internet. Hal ini sesuai dengan yang Darmawan (2012) nyatakan bahwa aplikasi mobile learning terdiri dari versi online dan offline, aplikasi edukasi versi offline dapat diakses berulangulang.

Aplikasi bahan ajar Determinan dan Invers Matriks terdiri dari beberapa komponen yang menyusunnya, yaitu halaman awal, menu "Belajar" yang terdiri dari KD dan tujuan, masalah, materi, kuis dan tes (lihat Gambar 2.); dan menu "Tentang Aplikasi" yang terdiri dari informasi tombol, informasi aplikasi, dan profil pengembang (lihat gambar 3.).

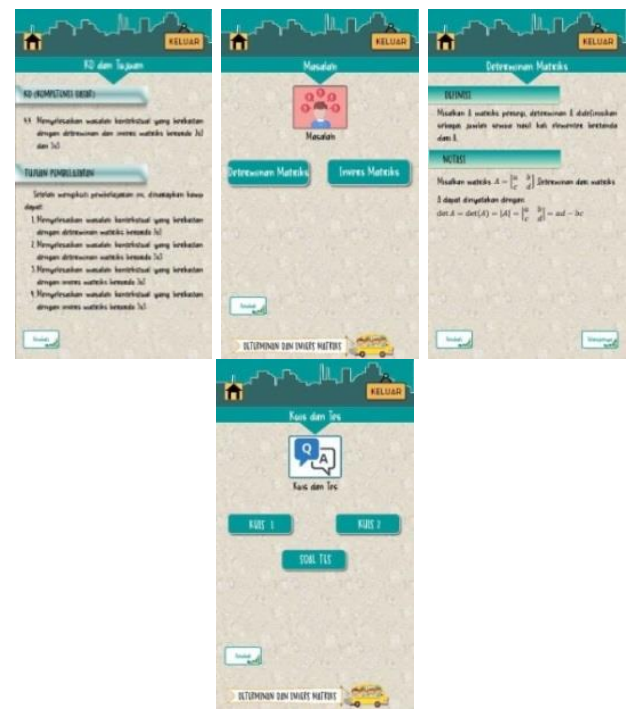

Gambar 2. Tampilan menu belajar
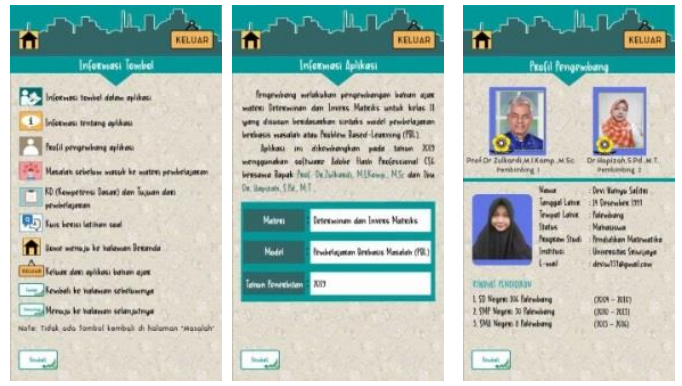

Gambar 3. Tampilan menu "Tentang Aplikasi"

Komponen aplikasi ini diadaptasi dari sistematika bahan ajar Depdiknas (2008) yang menurutnya paling tidak mencakup: petunjuk belajar, kompetensi yang akan dicapai, konten atau isi materi pembelajaran, informasi pendukung, latihan-latihan, petunjuk kerja, evaluasi, dan respon atau umpan balik terhadap hasil evaluasi.

\section{Deskripsi dan Analisis Pengembangan Bahan} Ajar

Pada tahap preliminary, hasil dari analisis menunjukkan bahwa lokasi penelitian, SMA Negeri 8 Palembang telah menerapkan kurikulum 2013, materi determinan dan invers matriks dipelajari di kelas 11 semester 1 . KD yang diambil ialah KD 3.4 Menganalisis sifatsifat determinan dan invers matriks berordo $2 \times$ 2 dan $3 \times 3$, dan KD 4.4 Menyelesaikan masalah kontekstual yang berkaitan dengan determinan dan invers matriks berorodo $2 \times 2$ dan $3 \times 3$.

Subjek penelitiannya adalah kelas XI.IPA 6, dipilih atas rekomendasi dari guru dan dikarenakan dari 34 orang hanya 1-2 orang saja yang menggunakan smartphone selain android. Desain dari bahan ajarnya mengikuti standard untuk SMA kelas 11, flowchart bahan ajar ini dapat dilihat pada gambar 4. Flowchart kemudian dikembangkan menjadi storyboard agar mempermudah dalam mengembangkan bahan ajar. 


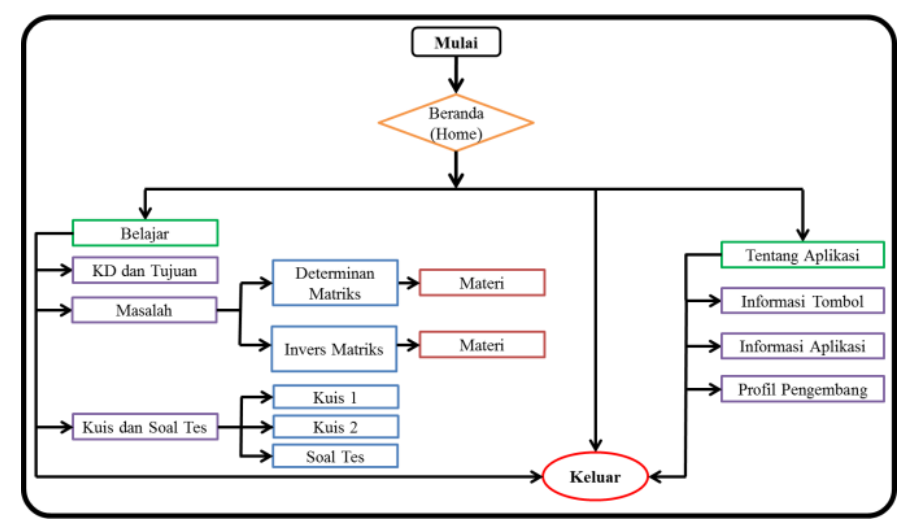

Gambar 4. Flowchart bahan ajar determinan dan invers matriks

Bahan ajar yang telah didesain kemudian diujicobakan pada tahap formative evaluation. Tahap pertama yaitu self evaluation, hanya terdapat sedikit perubahan pada tampilan informasi tombol dan KD dan tujuan. Hasil revisi ini disebut prototype 1 , diujikan ke tahap 2 yaitu prototyping yang terdiri dari expert review, one to one, small group, dan field test. Prototype 1 kemudian dinilai kevalidannya dari tahap expert review dan one to one. Bahan ajar kemudian mengalami perbaikan berdasarkan lembarlembar validasi yang telah diisi oleh validator dan lembar komentar saran oleh siswa. Berikut tabel 3 mengenai komentar/saran dan keputusan revisi yang diambil.

Tabel 3

Komentar/saran dan keputusan revisi pada tahap expert review

\begin{tabular}{|c|c|}
\hline Komentar/Saran & Keputusan Revisi \\
\hline $\begin{array}{l}\text { Validasi Media } \\
\text { - Peletakan gambar belum tepat } \\
\text { - Ukuran font tulisan agak kecil, perlu diperbesar } \\
\text { - Gunakan bahasa yang lebih simple } \\
\text { - Perbaiki tombol yang belum aktif } \\
\text { - Manfaatkan ruang kosong, sebaiknya frame penuh } \\
\text { - Waktu pemutaran video perlu diperhatikan } \\
\text { - Sebaiknya tambahkan waktu di pengerjaan kuis } \\
\text { - Kualitas isi, konstruk maupun bahasa pada bahan ajar } \\
\text { berbasis android sudah baik, sesuai dan komunikatif }\end{array}$ & $\begin{array}{l}\text { Ukuran font tulisan sedikit diperbesar, semula } 20.0 \mathrm{pt} \\
\text { menjadi } 21.0 \mathrm{pt} \\
>\text { Semua tombol telah aktif dan dapat berfungsi } \\
\text { semestinya } \\
>\text { Pada frame yang ruangnya terpakai sedikit, sudah } \\
\text { diperluas dengan memperbesar tombol-tombolnya } \\
\text { dan disejajarkan (pada tampilan menu "Belajar", } \\
\text { "Masalah", dan "Kuis") } \\
\text { Waktu pemutaran video sudah disesuaikan dengan } \\
\text { alokasi waktu pada RPP dalam proses pembelajaran }\end{array}$ \\
\hline
\end{tabular}

\section{Validasi Materi}

- Tombol memulai sebaiknya terlihat seperti tombol

- Video terlalu cepat sehingga ada informasi yang belum sempat dibaca

- Layout menu dimanfaatkan ruangnya

- Pada video sediakan tombol pause dan stop yang memiliki fungsi semestinya

- Berikan nomor soal pada kuis

- Posisi tombol mulai kuis dinaikkan

- Perbaiki indikator

- Perhatikan kembali kalimat yang terlalu panjang

- Tambahkan materi ordo $3 \times 3$ dan pembahasan di kuis

- Ganti masalah yang memang kontekstual dalam kehidupan sehari-hari

- Materi determinan ordo $2 \times 2$ diperjelas lagi

- Materi determinan dan invers matriks ordo $3 \times 3$ dimasukkan dalam aplikasi
Tombol memulai diperlihatkan seperti tombol dengan mengubah background yang semula menyatu menjadi berbeda yaitu warna abu-abu

> Setiap video disediakan tombol "Play", "Pause", "Stop", dan "Fullscreen" yang berfungsi semestinya

Pada kuis sudah diberi nomor-nomor soal 1, 2, dan 3

$>$ Tombol mulai kuis dinaikkan hingga dibawah form pengisian data pengguna

$>$ Indikator diperbaiki menjadi 4 capaian indikator

$>$ Materi determinan dan invers matriks untuk ordo $3 \times$ 3 telah ditambahkan pada materi di aplikasi bahan ajar

> Materi determinan matriks ordo $2 \times 2$ ditambahkan rumus dan penjelasan yang biasa dipelajari di sekolah 


\section{JURNAL GANTANG. September 2020; V(2): 151 - 162 \\ p-ISSN. 2503-0671 \\ e-ISSN. 2548-5547}

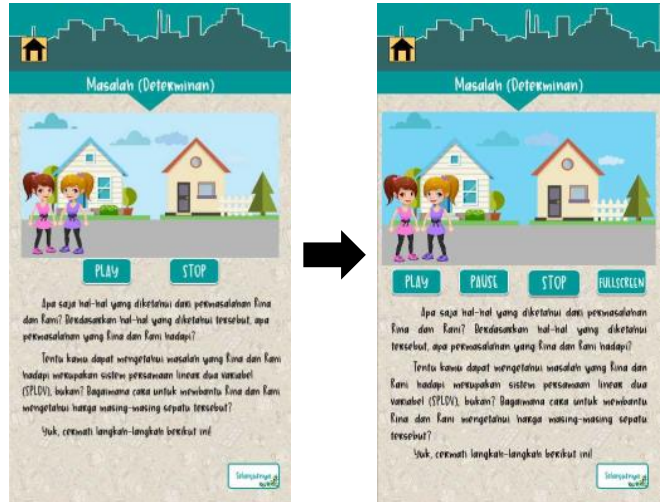

Gambar 5. Perbaikan tampilan masalah determinan
Gambar 5 menunjukkan salah satu perbaikan yang dilakukan pada bahan ajar.

Setelah direvisi, kemudian diperiksa kembali bahan ajar yang dikembangkan tersebut sampai dinyatakan valid oleh validator. Bahan ajar yang telah dinyatakan valid oleh semua validator menghasilkan prototype 2.

Prototype 2 kemudian diujikan ke tahap small group. Terdapat beberapa revisi berdasarkan lembar komentar saran dari peserta didik, dapat dilihat pada tabel 4.

Tabel 4.

Tanggapan peserta didik pada tahap small group

\begin{tabular}{|c|c|}
\hline Nama Peserta Didik & Komentar \\
\hline Kelompok 1: & - Aplikasinya sudah sangat bagus dan menarik \\
\hline Bagus Triyono & - Kuisnya menarik karena ada jawaban bener salahnya \\
\hline \multirow{4}{*}{ Apriadi } & - Tulisannya memudahkan kita membacanya \\
\hline & $\begin{array}{l}\text { - Kekurangannya masih di antara tombol kembali/home agak membingungkan karena } \\
\text { posisinya kurang pas (posisi tombol) }\end{array}$ \\
\hline & $\begin{array}{l}\text { - Tampilan aplikasi pertamanya menarik terus animasi pembahasannya itu bikin kita } \\
\text { jadi gak bosen, menarik dan mudah dipahami }\end{array}$ \\
\hline & $\begin{array}{l}\text { - Bagus belajar menggunakan aplikasi karena orang jaman sekarang sudah banyak } \\
\text { menggunakan aplikasi untuk belajar }\end{array}$ \\
\hline Kelompok 2: & - Banyakin soal-soal yang beragam \\
\hline Muhammad & - Materinya dapat dipahami \\
\hline Riduan & - Aplikasinya mudah dijalankan karena sudah ada informasi aplikasi di dalamnya \\
\hline \multirow{7}{*}{$\begin{array}{l}\text { Bintang Ardhi } \\
\text { Nugroho }\end{array}$} & - Ukuran hurufnya terlalu kecil, perlu agak dibesarin dikit lagi \\
\hline & - Tambahin di informasi aplikasi, buat aplikasinya pakai software apa \\
\hline & - Bisa belajar dimana-mana karena instan ada di HP \\
\hline & - Kurang efektif kalo di sekolah karena HP bisa habis batre \\
\hline & - Font nya lumayan bagus \\
\hline & - Pakai animasi lebih bagus biar gak bosen \\
\hline & - Desain tampilan awalnya menarik \\
\hline
\end{tabular}

Berdasarkan tabel 4, perbaikanperbaikan yang dilakukan pada bahan ajar yang dikembangkan yaitu menambahkan informasi software yang peneliti pakai untuk mengembangkan aplikasi di bagian "Informasi Aplikasi", ukuran fontnya sedikit diperbesar yang sebelumnya $21.0 \mathrm{pt}$ menjadi $22.0 \mathrm{pt}$ pada isi aplikasi bahan ajar, mengubah warna dan teks pada tombol-tombol di bagian "Masalah" dan "Kuis" menjadi warna seperti headernya, mengubah tampilan kotak rumus penting menjadi stripe dan warnanya menyatu dengan background agar terlihat menonjol.
Hasil dari revisi ini menjadi prototype 3 yang sudah dinyatakan praktis dengan rata-rata sebesar 81 berdasarkan hasil observasi dengan rincian yang dapat dilihat pada tabel 5. Prototype 3 ini telah dinyatakan valid dan praktis, sehingga siap untuk diujicobakan selanjutnya dalam proses pembelajaran.

Prototype 3 diujicobakan di kelas XI.IPA 6 SMA Negeri 8 Palembang tahun ajaran 2019/2020 yang berjumlah 34 orang. Penelitian ini dilakukan selama 3 pertemuan pada tahap field test, dapat dilihat pada tabel 6 . 
Tabel 5.

Hasil observasi pada tahap small group

\begin{tabular}{cccc}
\hline \multirow{2}{*}{ No. } & \multirow{2}{*}{ Pernyataan } & Pertemuan \\
\cline { 2 - 4 } 1 & Siswa mudah dalam menggunakan bahan ajar berbasis android & $\mathbf{1}$ & $\mathbf{2}$ \\
\hline 2 & Siswa termotivasi dalam mengerjakan soal yang ada pada bahan ajar berbasis android & 85 & 87,5 \\
\hline 3 & Materi determinan dan invers matriks dalam bahan ajar mudah dipahami oleh siswa & 75 & 75 \\
\hline 4 & Bahan ajar berbasis android membutuhkan waktu yang singkat dalam penggunaannya & 77,5 & 82,5 \\
\hline 5 & Siswa memiliki interaktivitas dalam menggunakan bahan ajar berbasis android & 85 \\
\hline & \multirow{2}{*}{ Jumlah } & 80 & 82,5 \\
\hline & Rata-rata & 402,5 & 407,5 \\
\hline & Kategori & $\mathbf{8 1 0}$ \\
\hline & & $\mathbf{8 1}$ \\
\hline & PRAKTIS
\end{tabular}

Pertemuan pertama, peneliti membagikan bahan ajar kepada setiap peserta didik, menyampaikan tujuan pembelajaran yaitu menentukan dan menyelesaikan masalah kontekstual yang berkaitan dengan determinan matriks ordo $2 \times 2$ dan $3 \times 3$.

Tabel 6.

Jadwal pelaksanaan field test

\begin{tabular}{lc}
\hline \multicolumn{1}{c}{ Waktu } & Kegiatan \\
\hline $\begin{array}{l}\text { Selasa, } \\
\text { 19 November 2019 }\end{array}$ & Pertemuan ke-1 \\
\hline Rabu, 20 November 2019 & Pertemuan ke-2 \\
\hline $\begin{array}{l}\text { Kamis, } \\
\text { 21 November 2019 }\end{array}$ & Tes Tertulis \\
\hline
\end{tabular}

Pertemuan kedua, peneliti menyampaikan tujuan pembelajaran yaitu menentukan dan menyelesaikan masalah kontekstual yang berkaitan dengan invers matriks ordo $2 \times 2$ dan $3 \times 3$. Setiap pertemuan, peneliti mengarahkan peserta didik untuk memahami, mempelajari materi maupun memecahkan masalah dari bahan ajar yang telah dibagikan. Pembelajaran dilakukan berdasarkan langkah-langkah pendekatan saintifik, yang berarti pembelajaran berpusat pada peserta didik atau peserta didik dituntut untuk lebih aktif. Setiap akhir pembelajaran, peserta didik diarahkan untuk mengerjakan soal kuis 1 dan 2 di rumah.

Pada pertemuan ketiga, dilaksanakan tes tertulis yang terdiri dari 2 soal uraian. Tes tertulis dilaksanakan untuk mengetahui efek potensial hasil belajar peserta didik setelah menggunakan bahan ajar determinan dan invers matriks. Hasil tes tertulis menunjukkan paling banyak peserta didik termasuk kategori tertinggi yaitu sebanyak 13 orang, kemudian kategori baik sebanyak 12 orang, kategori cukup sebanyak 4 orang dan kategori kurang sebanyak 5 orang. Nilai tertinggi sebesar 92,31 (baik sekali), nilai terendah sebesar 21,15 (kurang) dan nilai rata-rata diperoleh sebesar 61,77 dengan nilai KKMnya 70 , kategorinya dapat dilihat pada tabel 7 .

Tabel 7. Frekuensi hasil tes tertulis berdasarkan kategori nilai

\begin{tabular}{ccc}
\hline Nilai Akhir & Kategori Nilai & Frekuensi \\
\hline $80<N_{A} \leq 100$ & Baik Sekali & 13 \\
\hline $60<N_{A} \leq 80$ & Baik & 12 \\
\hline $40<N_{A} \leq 60$ & Cukup & 4 \\
\hline $20 \leq N_{A} \leq 40$ & Kurang & 5 \\
\hline $0 \leq N_{A} \leq 20$ & Gagal & 0 \\
\hline & Jumlah & 34 \\
\hline
\end{tabular}

Setelah pelaksanaan observasi dan tes, peneliti melakukan wawancara untuk tahap field test. Wawancara dilakukan terhadap 4 orang peserta didik yang dipilih berdasarkan kategori kemampuan peserta didik dari hasil tes dan rekomendasi Pak H. Jurnaidi, M.Pd selaku guru matematika di kelas XI.IPA 6. Keempat peserta didik yang dipilih tersebut yaitu NA, MSA, AFN, dan RSA. Wawancara ini dilaksanakan pada hari Jumat, 29 November 2019 di perpustakaan SMA Negeri 8 Palembang.

Hasil wawancara menunjukkan untuk masalah yang disajikan dalam aplikasi sudah sesuai dengan konteks kehidupan sehari-hari. Harga parkir biaya motor pada masalah yang disajikan sudah sesuai dengan faktanya menurut 


\section{JURNAL GANTANG. September 2020; V(2): 151 - 162 \\ p-ISSN. 2503-0671 \\ e-ISSN. 2548-5547}

MSA. Penyelesaiannya juga menurut pendapat mereka sudah jelas dan sudah sesuai dengan determinan matriks.

Peneliti : Apakah penyelesaiannya sudah sesuai KD dan Tujuan?

AFN : Sudah, sudah sesuai.

Dari penyelesaian kemudian ke materi, menurut mereka sudah jelas.

Peneliti : Terus untuk menurut $\mathrm{T}$ mengenai materi yang disajikan kan ada determinan ordo $2 \times 2$, trus $3 \times 3$ dan invers matriksnya juga. Apakah sudah jelas, mengerti gitu?

AFN : Jelas kok, karena kan disitu sudah dikasih cara langkah-langkahnya penyelesaian soal-soal gitu.

Selain itu, pada bagian kuis keempatnya menyatakan sudah sesuai dari soal, feedback maupun pembahasannya. Tampilan awal dari aplikasi juga menarik minat mereka untuk melihat aplikasinya lebih dalam.

Bagian-bagian yang melengkapi aplikasi seperti gambar, animasi, video atau ilustrasi mendukung mereka memahami materi maupun masalah. Menurut MSA mereka dapat memutar video tersebut berulang kali. Dengan adanya video juga menurut AFN bisa dibayangin secara logika bagaimana masalah itu. Keempat peserta didik tersebut juga menyebutkan penyajian aplikasi sudah terurut.

Berkaitan dengan hal tersebut, penggunaan bahan ajar berbasis android dapat meningkatkan daya tarik peserta didik untuk belajar yang lebih besar dibandingkan menggunakan buku teks biasa (Sari et al., 2020). Bahkan, RSA dalam wawancara menyebutkan pembelajaran dengan aplikasi dapat bermanfaat karena dapat belajar dimanapun dengan memanfaatkan aplikasi yang ada pada smartphone peserta didik.

Peneliti : Manfaatnya apa?

RSA : Manfaatnyo jadi kalo misal kito lagi dak katek gawe disini kan, dak mungkin kito bawa buku matematika pergi ke mall apo cakmano, jadi kalo kito lagi katek gawe kito biso buka HP kan, jadi HP tuh fungsinyo bukan cuma untuk main game, chatingan tapi biso untuk belajar jugo.

Berdasarkan hal inilah yang juga menjadi salah satu pendukung penelitian peneliti karena aplikasi yang dikembangkan cukup memberikan dampak positif bagi mereka, dengan fitur-fitur utama yang mesti dimiliki agar peserta didik tertarik untuk belajar. Bahkan, belajar dapat lebih praktis dan dapat dilakukan dimana saja sesuai tanggapan peserta didik pada saat wawancara.

\section{Kesimpulan}

Penelitian ini telah menghasilkan aplikasi bahan ajar berbasis android materi determinan dan invers matriks untuk SMA kelas XI yang valid dan praktis. Bahan ajar yang dihasilkan ini telah dievaluasi kevalidannya oleh 4 orang validator ahli baik media maupun materi. Bahan ajar yang dihasilkan ini juga telah dievaluasi kepraktisannya dengan observasi yang menunjukkan bahan ajar terkategori praktis dengan perolehan rata-rata sebesar 81 .

Bahan ajar determinan dan invers matriks yang dikembangkan memiliki efek potensial terhadap hasil belajar peserta didik di kelas XI.IPA 6 SMA Negeri 8 Palembang tahun ajaran 2019/2020 dengan rata-rata kategori baik. Dari 34 subjek penelitian, menunjukkan 13 orang memiliki kemampuan dalam kategori sangat baik, 12 orang terkategori baik, 4 orang terkategori cukup, dan 5 orang terkategori kurang.

\section{Referensi}

Aksin, N., Ngapiningsih, Miyanto, \& Astuti, A. Y. (2017). Detik-detik UNBK matematika untuk SMA/MA Program IPA/peminatan matematika dan IPA. Klaten: Intan Pariwara.

Arikunto, S. (2014). Prosedur penelitian, suatu pendekatan praktik (Ed. XV). Jakarta: PT Rineka Cipta.

Corlan, M. (2011). Developing for mobile devices with the adobe flash platform. 
Retrieved from https://www.yumpu.com/en/document/read /33655762/developing-for-android-withthe-flash-platform-mihai-corlan

Darmawan, D. (2012). Pendidikan Teknologi informasi dan komunikasi teori dan aplikasi. Bandung: PT Remaja Rosdakarya.

Depdiknas. (2008). Panduan pengembangan bahan ajar. Jakarta: Depdiknas.

Fazar, I., Zulkardi, \& Somakim. (2016). Pengembangan bahan ajar program linear menggunakan aplikasi geogebra. Jppm, 9(1), 6-11.

Gerantabee, F., \& AGI Creative Team. (2012). Adobe Flash Professional CS6 digital classroom. Indianapolis: John Wiley \& Sons, Inc.

Ghufron, M. N., \& Risnawita, R. S. (2012). Gaya belajar: kajian teoritik. Yogyakarta: Pustaka Belajar.

Google Developer Training Team. (2016). Android developer fundamentals course (Learn to develop Android Applications). Retrieved from Google Developer Training Team website: https://google-developertraining.github.io/android-developerfundamentals-course-concepts/en/androiddeveloper-fundamentals-course-concepten.pdf.

Halid, A. (2016). Analisis kesulitan siswa dalam menyelesaikan soal matrix siswa kelas XII SMA Negeri 1 Pammana Kabupaten Wajo (Skripsi, UIN Alauddin, Makassar) Retrieved from http://repositori.uinalauddin.ac.id/10300/

Hidayah, N. S. (2017). Pengembangan bahan ajar melalui pendekatan saintifik mata pelajaran al qur'an hadist kelas VII di MTs Negeri Krian Sidoarjo (Skripsi, UIN Sunan Ampel Surabaya). Retrieved from http://digilib.uinsby.ac.id/22027/

Istikomah, D. A., \& Jana, P. (2018). Kemampuan pemahaman konsep matematis mahasiswa melalui pendekatan pembelajaran saintifik dalam perkuliahan aljabar matrik. Jurnal Pendidikan Dasar PerKhasa, 927-932.
Jacoebson, D. A. (2009). Methods for teaching. Yogyakarta: PustakaPelajar.

Jazuli, M., Azizah, L. F., \& Meita, N. M. (2018). Pengembangan Bahan ajar elektronik berbasis android sebagai media interaktif. LENSA (Lentera Sains): Jurnal Pendidikan IPA, 7(2), 47-65. doi: 10.24929/lensa.v7i2.22

Kemdikbud. (2017).

Matematika SMA/MA/SMK/MAK Kelas XI. Jakarta: Kemdikbud.

Kementerian Pendidikan dan Kebudayaan. (2014). Materi Pelatihan implementasi kurikulum 2013 tahun 2014. Jakarta: Badan Pengembangan Sumber Daya Manusia Pendidikan dan Kebudayaan dan Penjaminan Mutu Pendidikan.

Krismantono, R. R., \& Purnami, A. S. (2016). Analisis kesalahan dalam menyelesaikan soal matematika. Prosiding Seminar Nasional Etnomatnesia, 177-181. Yogyakarta: Universitas Sarjanawiyata Tamansiswa.

Menristekdikti. (2018). Pengembangan iptek dan pendidikan tinggi di era revolusi industri 4.0 (siaran pers). Retrieved from Kemenristekdikti / Badan Riset dan Inovasi Nasional website: http://www.ristekdikti.go.id/siaranpers/pengembangan-iptek-dan-pendidikantinggi-di-era-revolusi-indutri-4-0/

Mulyono, B., \& Hapizah, H. (2018). Pemahaman konsep dalam pembelajaran matematika. KALAMATIKA Jurnal Pendidikan Matematika, 3(2), 103-122. doi: 10.22236/kalamatika.vol3no2.2018pp103122

Musfiqon, \& Nurdyansyah. (2015). Pendekatan pembelajaran saintifik. Sidoarjo: Nizamia Learning Center.

Novitasari, D. (2016). Pengaruh penggunaan multimedia interaktif terhadap kemampuan pemahaman konsep matematis siswa. FIBONACCI: Jurnal Pendidikan Matematika Dan Matematika, 2(2), 8-18. doi: $10.24853 / \mathrm{fbc} .2 .2 .8-18$ 
JURNAL GANTANG. September 2020; V(2): 151 - 162

p-ISSN. 2503-0671

e-ISSN. 2548-5547

Nurrasyid, M. (2019). Pengembangan Media pembelajaran kimia berbasis android pada materi bentuk molekul untuk peserta didik kelas X di SMA Negeri 2 Bandar Lampung (Skripsi, Universitas Lampung, Lampung). Retrieved from http://digilib.unila.ac.id/id/eprint/61108

Palaki, Y., \& Fahinu. (2015). Pengaruh Pendekatan saintifik terhadap kemampuan pemahaman matematika siswa kelas VIII SMP Negeri 9 Kendari pada materi operasi aljabar. Jurnal Penelitian Pendidikan Matematika, 3(3), 153-166.

Qusthalani. (2018). Portal rumah belajar, cara pintar belajar tanpa kertas. retrieved from pena rumah belajar. Retrieved from: http://pena.belajar.kemdikbud.go.id/2018/1 2/portal-rumah-belajar-cara-pintar-belajartanpa-kertas/

Rahayu, I. D. (2018). Opini: Revolusi Industri 4.0 dan pengaruhnya pada sistem pendidikan. Retrieved from KAMIL ITB website: http://kamilpasca.itb.ac.id/opinirevolusi-industri-4-0-dan-pengaruhnyapada-sistem-pendidikan/

Retnoningrum, A., Dasna, I. W., \& Santoso, A. (2016). Penggunaan Pendekatan saintifik dalam bahan ajar berbantuan multimedia materi konsep larutan untuk SMK agribisnis produksi tanaman. Pros. Semnas Pend. IPA Pascasarjana UM, 1, 542-548. Malang: Universitas Negeri Malang.

Sari, M. S., Hapizah, Susanti, E., \& Scristia. (2020). Development of teaching materials arithmetic sequence and series based on android for problem based learning. National Conference on Mathematics Education (NaCoMe), 1-9. doi: 10.1088/1742-6596/1480/1/012024

Sulastra, K., Wiarta, I. W., \& Manuaba, I. B. S. (2015). Penerapan pendekatan saintifik dengan penilaian proyek untuk meningkatkan kemampuan pemahaman konsep dan hasil belajar keterampilan matematika siswa kelas IV SD. E-Journal PGSD Universitas Pendidikan Ganesha 
Safitri, Zulkardi \& Hapizah: Bahan Ajar Determinan dan Invers...(16) 